\title{
Metabolism and Udder Health at Dry-Off in Cows of Different Breeds and Production Levels
}

\author{
M. O. Odensten, ${ }^{\star 1}$ B. Berglund, $†$ K. Persson Waller, $\neq \S$ and K. Holtenius ${ }^{\star}$ \\ *Department of Animal Nutrition and Management, Swedish University of Agricultural Sciences, SE-753 23 Uppsala, Sweden \\ †Department of Animal Breeding and Genetics, Swedish University of Agricultural Sciences, Box 7023, SE-750 07 Uppsala, Sweden \\ ‡Department of Pigs, Poultry and Ruminants, National Veterinary Institute (SVA), SE-751 89 Uppsala, Sweden \\ §Department of Clinical Sciences, Swedish University of Agricultural Sciences, SE-750 07 Uppsala, Sweden
}

\begin{abstract}
The effects of milk yield at dry-off (DO), different calving intervals (CI; 12 and $15 \mathrm{mo}$ ) and breed on metabolism and udder health were studied in 56 primiparous and multiparous cows of the Swedish Red and White (SRB) and Swedish Holstein (SH) breeds. The cows were dried off $55 \pm 5 \mathrm{~d}$ prior to expected parturition. They were fed $4 \mathrm{~kg}$ of $\mathrm{DM}$ as silage and wheat straw ad libitum for $5 \mathrm{~d}$, and were milked in the morning of $\mathrm{d} 2$ and 5. Depending on their daily milk yield, the cows were divided into 3 numerically equal groups on $2 \mathrm{~d}$ during the week prior to DO: low (LY; 5.0 to $11.4 \mathrm{~kg}$ of milk/d, $\mathrm{n}=19$ ), medium (MY; 11.5 to $17.7 \mathrm{~kg}$ of milk/d, $\mathrm{n}=19$ ), and high (HY; 17.8 to $29.5 \mathrm{~kg}$ of milk/d, $\mathrm{n}=18$ ). The plasma cortisol concentration increased during DO only in MY and HY cows. Plasma nonesterified fatty acids increased during DO in all groups, but the maximum nonesterified fatty acid concentration was related to the milk yield prior to DO. The plasma glucose level during the DO period was not significantly affected by yield, but the insulin concentration decreased after DO, with a more pronounced drop in the HY group. The CI 15-mo group had a higher glucose level and tended to have a higher insulin level in plasma than the CI 12-mo group before DO. They also had a higher body condition than the CI 12-mo group. The results indicate that the CI 15mo cows had a more positive nutrient balance. There were no effects of CI on milk production or composition during DO. The SRB and SH breeds did not differ in any of the measured plasma parameters or milk production. However, the lower somatic cell counts in SRB than in SH observed before and during DO, as well as after parturition, were attributed to being an effect of breed. The proportion of cows with intramammary infections (IMI) was significantly lower just after calving in the LY group than in the other yield groups.
\end{abstract}

Received December 29, 2005.

Accepted October 27, 2006.

${ }^{1}$ Corresponding author: Martin.Odensten@huv.slu.se
At 2 and 3 wk after DO, significantly fewer cows in the LY group had open teat canals compared with the HY and MY groups, respectively, but teat-end condition did not differ between yield groups. The yield before DO did not significantly influence the somatic cell counts during the first $4 \mathrm{wk}$ after parturition or the presence of IMI $4 \mathrm{wk}$ after parturition. We concluded that in the present study, higher milk yield prior to DO gave rise to a more pronounced metabolic response and a higher risk of contracting IMI during the dry period, at calving, or both, but yield at DO did not have any long-term effects on udder health. A prolonged CI did not facilitate a rapid decrease in milk production. The SRB and SH breeds responded equally in decreasing the milk production during $\mathrm{DO}$, but the SRB breed had lower somatic cell counts.

Key words: dry-off, dairy cow, metabolism, udder health

\section{INTRODUCTION}

Common dry-off (DO) procedures include intermittent or abrupt cessation of milking and reduced nutrient supply (Skidmore et al., 1997). Both procedures lead to inhibited milk secretion, but via independent mechanisms (McFadden et al., 1995). Cessation of milking causes a regression of mammary secretory epithelial cells, whereas the reduced nutrient supply causes down-regulation of the mammary glucose transport systems, reduced blood flow, and a prolonged transit time of blood through the mammary gland (Farr et al., 2000; Shennan and Peaker, 2000; Stefano et al., 2002). We recently showed that common DO procedures may induce a significant metabolic challenge for the cows (Odensten et al., 2005a). Cows that consumed only straw during the DO period were more affected than cows that were also fed $4 \mathrm{~kg}$ of DM/d of silage during the DO period. However, both treatments were equally efficient in reducing milk production (Odensten et al., 2005a). In that study, all cows yielded approximately the same amount of milk prior to DO, and it was thus not possible to study the influ- 
ence of milk yield on metabolic load. High milk production at DO has been shown to increases the risk of having IMI at calving (Dingwell et al., 2004; RajalaSchultz et al., 2005). The significance of level of milk production prior to DO on the cow's metabolism has not yet been elucidated.

A common practice in dairy herds with intensive milk production has been to breed cows with the aim of establishing a calving interval (CI) close to $12 \mathrm{mo}$ (Strandberg and Oltenacu, 1989; Brand and Warner, 1997). More recent studies have shown that an extended CI has beneficial effects on high-producing cows because of a better utilization of the milk production capacity (Arbel et al., 2001; Österman and Bertilsson, 2003) and improved fertility, because an extended CI prolongs the time available to resume reproductive functions (Ratnayake et al., 1998) and reduces udder health problems caused by high milk production at DO (Rehn et al., 2000).

During the 2003 Swedish milk-recording year, 46\% of the enrolled dairy cows in Sweden were of the Swedish Red and White (SRB) breed, whereas $48 \%$ of the cows belonged to the Swedish Holstein (SH) breed (Swedish Dairy Association, 2005). The SRB breed is a dual-purpose breed with slightly lower milk production and lower incidence of mastitis than $\mathrm{SH}$ cows (Emanuelson et al., 1993; Swedish Dairy Association, 2005). Our earlier studies on metabolism and health at DO (Odensten et al., 2005a,b) included only SRB. Because there might be breed differences (e.g., in metabolism and in milk production) at DO, it would be relevant to make comparisons between SRB and SH.

An objective of the study was to investigate the effects of daily milk yield just before DO on milk volume reduction and intermediary metabolism during DO. The effects of daily milk yield on udder health during DO and following parturition were also studied. Other aims were to study whether a prolonged CI would facilitate a rapid reduction in milk volume during $\mathrm{DO}$ and whether breed (SRB or SH) would affect the outcome.

\section{MATERIALS AND METHODS}

\section{Animals, Management, and Experimental Design}

The study was carried out on the experimental farm of the Department of Animal Breeding and Genetics, Swedish University of Agricultural Sciences, from August 2003 to January 2005. Initially, 64 dairy cows of the SRB and SH breeds were entered in the experiment. Eight of these cows had a milk yield lower than $5 \mathrm{~kg}$ of milk/d in the week prior to DO and were excluded from further investigations. Thus, 56 cows $(\mathrm{SRB}=38 ; \mathrm{SH}=18)$ were included in the study. Of the SRB cows, 21 were primiparous and 17 were mul- tiparous, whereas 8 of the $\mathrm{SH}$ cows were primiparous and 10 were multiparous. The SRB cows were bred with sires that were indexed for high $(\mathbf{H F I} ; \mathrm{n}=22)$ or low (LFI; $\mathrm{n}=16)$ milk fat percentage, but had the same amount of energy produced in milk (Janson, 1993). All cows participated in a long-term trial with 2 different CI: 12 mo (CI-12; $\mathrm{n}=39)$ and 15 mo (CI-15; $\mathrm{n}=17$; Rehn et al., 2000).

Throughout the experiment, the cows were housed in individual tie stalls with sawdust bedding. Drinking water was available in automatic water bowls, and the cows had free access to salt licks. Body condition scoring was conducted once during the week before DO. Cows were fed individually according to Swedish standards for ME, protein, and minerals (Spörndly, 2003) based on actual milk yield and stage of gestation. Prior to DO, silage, concentrates, and minerals were fed at $0530,0830,1300$, and $1600 \mathrm{~h}$ each day. During the DO period ( 1 to 5 ), the cows were fed $4 \mathrm{~kg}$ of DM/ $\mathrm{d}$ as silage and were fed wheat straw ad libitum. Silage refusals were registered during the DO period. After the DO period, the cows were introduced to the dry period feed ration, which was composed according to Swedish standards (Spörndly, 2003). The chemical composition and DM content of the individual feedstuffs are shown in Table 1 . The cows were milked twice each day (i.e., at 0600 and 1600 h) during lactation and once daily on $\mathrm{d} 2$ and 5 during DO. The Uppsala Local Ethics Committee approved the experimental design.

\section{Samplings and Analyses}

Feed. Samples of silage and concentrates were collected once weekly. Four weekly samples were pooled prior to analysis. Daily straw samples were collected when straw was included in the diet and were pooled into weekly samples prior to analyses. The feed components were dried at $60^{\circ} \mathrm{C}$ in a forced-air oven for $24 \mathrm{~h}$ and ground in a hammer mill (1-mm screen). The DM content was obtained by drying the ground feed at $105^{\circ} \mathrm{C}$ overnight. The dried feed components were ashed at $550^{\circ} \mathrm{C}$ for $5 \mathrm{~h}$ to determine the $\mathrm{OM}$ in the feed. Silage and straw samples were analyzed for NDF according to Goering and Van Soest (1970). Feeds were analyzed for CP by a fully automated Kjeldahl procedure (Technicon, Solna, Sweden). Metabolizable energy in the feeds was calculated from in vitro digestibility (Lindgren, 1979). Means from the feed analysis are presented in Table 1.

Milk. Measurements of daily milk yield (sum of morning and evening milkings, $\mathrm{kg}$ of milk/d), milk composition (fat, lactose, and protein), and SCC (Fossomatic 5000; N Food Electric, Hillerød, Denmark) were 
Table 1. Dry matter content, chemical composition, and calculated values for ME, crude fat, CP, and NDF

\begin{tabular}{|c|c|c|c|c|c|c|}
\hline Item & Silage & Straw & $\begin{array}{c}\text { Standard } \\
\text { concentrates }\end{array}$ & Prefect $^{1}$ & Unik $52^{1}$ & $\begin{array}{c}\text { Mineral } \\
\text { feed }\end{array}$ \\
\hline $\mathrm{DM}, \%$ & 33.6 & 96.6 & 88.0 & 89 & 89 & 98 \\
\hline $\mathrm{ME}, \mathrm{MJ} / \mathrm{kg}$ of $\mathrm{DM}$ & 10.7 & $6.6^{2}$ & 13.2 & 14 & 14 & \\
\hline $\mathrm{AAT}^{3}{ }^{3} \mathrm{~g} / \mathrm{kg}$ of DM & $71^{2}$ & $45^{2}$ & 114.8 & 140 & 157 & \\
\hline $\mathrm{PBV},{ }^{4} \mathrm{~g} / \mathrm{kg}$ of $\mathrm{DM}$ & $45^{2}$ & $-35^{2}$ & 6.2 & $26^{2}$ & $50^{2}$ & \\
\hline $\mathrm{CP}, \mathrm{g} / \mathrm{kg}$ of $\mathrm{DM}$ & 154 & $69^{2}$ & 190.9 & 243 & 290 & \\
\hline Crude fat, $\mathrm{g} / \mathrm{kg}$ of $\mathrm{DM}$ & $20^{2}$ & $20^{2}$ & 30.8 & 101 & 96 & \\
\hline $\mathrm{NDF}, \mathrm{g} / \mathrm{kg}$ of DM & 504 & 723.5 & 253.2 & 275 & 297 & \\
\hline $\begin{array}{l}\text { Ash, \% of DM } \\
\mathrm{pH}\end{array}$ & $\begin{array}{l}9.5 \\
4.2\end{array}$ & 8.6 & $2.8^{2}$ & 8.4 & 8.5 & \\
\hline Calcium, $\mathrm{g} / \mathrm{kg}$ of DM & $6.0^{2}$ & $7.5^{2}$ & $0.6^{2}$ & $7.9^{2}$ & $11.2^{2}$ & 149 \\
\hline Phosphorus, g/kg of DM & $2.7^{2}$ & $2.6^{2}$ & $4.0^{2}$ & $4.5^{2}$ & $5.6^{2}$ & 66 \\
\hline Magnesium, g/kg of DM & $1.8^{2}$ & $2.8^{2}$ & $1.3^{2}$ & $5.6^{2}$ & $4.5^{2}$ & 94 \\
\hline Sodium, $\mathrm{g} / \mathrm{kg}$ of $\mathrm{DM}$ & - & $3.0^{2}$ & $0.3^{2}$ & - & - & 71 \\
\hline
\end{tabular}

${ }^{1}$ Commercial concentrates manufactured by Lantmännen (Uppsala, Sweden).

${ }^{2}$ Values from the feedstuff table (Spörndly, 2003).

${ }^{3} \mathrm{AAT}=\mathrm{AA}$ absorbed in the small intestine (Spörndly, 2003).

${ }^{4} \mathrm{PBV}=$ protein balance in the rumen (Spörndly, 2003).

taken once $1 \mathrm{wk}$ prior to DO. The same measurements were also made on milk samples taken on 4 occasions during the week before DO, at evening milkings on $d$ -6 and -3 , at morning milkings on $d-5$ and -2 before $\mathrm{DO}$, and at the 2 milkings during DO. Cow composite SCC was also measured once weekly for $4 \mathrm{wk}$ after parturition. Quarter milk samples were collected aseptically after the morning milking twice ( $2 \mathrm{~d}$ apart) for $4 \mathrm{wk}$ prior to DO (PD4), at the 2 milkings during DO, and twice (2 d apart) at 1 (PP1) and 4 (PP4) wk postparturition (PP). All quarter milk samples were analyzed for bacteriological growth using accredited methods at the Section of Mastitis, National Veterinary Institute, Uppsala, Sweden. An IMI was defined as a bacteriological finding of major or minor udder pathogens on at least 1 of 2 sampling occasions per period (PD4, DO, PP1, and PP4). Major pathogens were all udder pathogens other than the minor udder pathogens Corynebacterium bovis and CNS.

Milk Leakage, Teat Condition, and Teat Closure. During DO, the animals were inspected for milk leakage (i.e., milk observed dripping from one or more teats). In 37 cows, the teat-end condition was scored according to Neijenhuis et al. (2000) once weekly after DO. All teats were examined starting the first week after DO. Five scores $(0=$ none, $\mathrm{A}=$ slight, $\mathrm{B}=$ moderate, $\mathrm{C}=$ thick, and $\mathrm{D}=$ extreme callosity) were used, incorporating both smooth (1) and rough (2) callosity. Teat closure was investigated once weekly after DO in 2 teats (random choice of right or left side) in the same 37 cows according to Dingwell et al. (2004). If both teats were scored as closed for 2 consecutive weeks, the teats were considered permanently closed and no more investigations were performed. The same conditions applied for the examinations of teat-end callosity.

Blood. Blood samples were collected into evacuated tubes containing sodium heparin as anticoagulant (Venoject; Terumo Europe N.V., Leuven, Belgium). Blood was taken from one of the jugular veins between 0900 and $1000 \mathrm{~h}$ on $\mathrm{d}-4,-2,1,3,5,8,10,12,15$, and 19 in relation to DO d 1 . Blood was centrifuged for 8 min at $1,800 \times g$, and plasma was stored at $-20^{\circ} \mathrm{C}$ until analyzed for cortisol, NEFA, BHBA, urea, glucose, and insulin. Cortisol was analyzed using a commercial kit (Coat-A-Count; Diagnostic Products Corporation, Los Angeles, CA). Enzymatic determinations were used for NEFA (NEFA C; Wako Chemicals Inc., Richmond, VA), glucose (Gluco-quant Glucose/HK; Roche Diagnostics, Boehringer Mannheim, Mannheim, Germany), and insulin (Mercodia Ultrasensitive Bovine Insulin ELISA; Mercodia AB, Uppsala, Sweden). The concentration of BHBA was determined using a colometric method (BHBA liquicolor; Stanbio Laboratory, Boerne, TX). Urea was determined on a Technicon Autoanalyzer (Technicon AutoAnalyzer II, Technicon method no. SE40001FD4; Technicon GmbH, Frankfurt am Main, Germany).

\section{Statistical Analysis}

Statistical analyses of variance were performed using PROC MIXED (SAS program, version 8.02; SAS Institute, 2001). Least squares means (LSM) were compared with the comparison-wise error rate after a significant $F$-test. Least significant difference values were based on calculations with $t_{0.975}$. Values before DO were calculated on individual values and used in 
Table 2. Distribution of breed [Swedish Red and White (SRB) and Swedish Holstein (SH) breeds], lactation number (primiparous and multiparous), and calving interval [12 mo (CI-12) or 15 mo (CI-15)] among cows $(\mathrm{n}=56)$ in each yield group [low yield (LY), $\mathrm{n}=19$; medium yield (MY), $\mathrm{n}=19$; high yield (HY), $\mathrm{n}=18$ ]

\begin{tabular}{|c|c|c|c|c|c|c|}
\hline \multirow{2}{*}{$\begin{array}{l}\text { Yield } \\
\text { group }\end{array}$} & \multicolumn{2}{|c|}{ Breed } & \multicolumn{2}{|c|}{ Lactation } & \multicolumn{2}{|c|}{ CI } \\
\hline & SRB & $\mathrm{SH}$ & Primiparous & Multiparous & CI-12 & CI-15 \\
\hline LY & 15 & 4 & 7 & 12 & 14 & 5 \\
\hline MY & 11 & 8 & 10 & 9 & 13 & 6 \\
\hline $\mathrm{HY}$ & 12 & 6 & 12 & 6 & 12 & 6 \\
\hline
\end{tabular}

the ANOVA for blood parameters according to model 1. The effect of the SRB selection lines, LFI and HFI, was not significant in any of the blood parameters and were therefore not included in the final model for blood parameters. The cows were divided into 3 numerically equal groups, low $(\mathbf{L Y}=5.0$ to $11.4 \mathrm{~kg}$ of $\mathrm{milk} / \mathrm{d} ; \mathrm{n}=$ 19), medium ( $\mathbf{M Y}=11.5$ to $17.7 \mathrm{~kg}$ of $\mathrm{milk} / \mathrm{d} ; \mathrm{n}=19$ ), and high $(\mathbf{H Y}=17.8$ to $29.5 \mathrm{~kg}$ of milk/d; $\mathrm{n}=18)$ yield depending on their daily milk production (mean of 2 test days, each including 2 milkings) in the week prior to DO. The study was carried out over a period of $16 \mathrm{mo}$, and the cows in each yield group were evenly distributed over this period of time. The distribution of breed, lactation number, and CI in each yield group is given in Table 2. The time factor (Day) was divided into 3 classes (PER 1), defining data as before, during, or after DO. The model used different variances among subjects for the 3 period classes (PER 1) and different autoregressive covariance structures for the withinsubject variations. Nonesterified fatty acid values were not normally distributed, and the statistical analysis was performed on the log-transformed values. Interactions were tested and the ones that were not significant were dropped from the model. The interactions Yield $\times$ Day and CI $\times$ Day were retained in the model to retrieve LSM values:

\section{Model 1}

Class: ID Yield Breed Day Par CI PER 1

$\mathbf{Y}_{\text {blood }}=$ Yield Breed Day Par CI Yield $\times$ Day CI $\times$ Day/OUTPRED=N1 DDFM=SAT REPEATED/ $\mathrm{SUB}=\mathrm{ID}$ TYPE$=\mathrm{AR}(1) \mathrm{GROUP}=\mathrm{PER} 1$

The daily milk yield, milk composition, and SCC before and during DO were analyzed using model 2 . The data were grouped into 2 period classes (before and during DO) before analyses, and different variances among subjects for the 2 period classes (PER 2) and different autoregressive covariance structures for the within-subject variations were used. A separate analysis using model 2 was made for milk SCC postparturition. Because SCC was not normally distributed, logtransformed values were used in the statistical mod- els. The interaction Yield $\times$ Day was retained in the model for retrieving LSM values. Calving interval and parity were not significant and were deleted from the final model:

Model 2

Class: ID Yield Breed Day PER 2

$\mathbf{Y}_{\text {milkcomp }}=$ Yield Breed Day Yield $\times$ Day/OUT$\mathrm{PRED}=\mathrm{N} 1 \quad \mathrm{DDFM}=\mathrm{SAT} \quad$ REPEATED/SUB=ID TYPE=AR(1) GROUP=PER 2

ID = cow ID

Yield $=3$ yield groups; LY, MY, and HY

Breed $=$ breed of the cow (SH or SRB)

Day $=$ sample date $($ in relation to DO referred as d 1)

Par $=$ parity (primiparous or multiparous cows)

$\mathrm{CI}=12 \mathrm{mo}$ and $15 \mathrm{mo}$

PER 1 = prior to DO, during DO, and after DO

PER 2 = prior to DO, during DO

Differences between yield groups in numbers of IMI (major udder pathogens and all udder pathogens) on cow and udder quarter levels at DP4, DO, PP1, and PP4 were evaluated using Fisher's exact test (cow level) and $\chi^{2}$ (quarter level; Statistica, StatSoft Inc., Tulsa, OK). Differences in disease incidence, teat closure, and teat-end score were also evaluated using Fisher's exact test.

\section{RESULTS}

\section{Feed and Milk Yield}

Overall, the DO period started $55 \pm 5 \mathrm{~d}$ prior to parturition. The mean \pm SD daily milk yield the week prior to DO in LY cows was $8.6 \pm 0.5 \mathrm{~kg} / \mathrm{d}$ (ranging from 5.0 to $11.4 \mathrm{~kg} / \mathrm{d}$ ). The corresponding figures for $\mathrm{MY}$ and HY cows were $14.7 \pm 0.5 \mathrm{~kg} / \mathrm{d}$ (ranging from 11.5 to $17.7 \mathrm{~kg} / \mathrm{d}$ ), and $21.2 \pm 0.5 \mathrm{~kg} / \mathrm{d}$ (ranging from 17.8 to $29.5 \mathrm{~kg} / \mathrm{d}$ ), respectively. During DO, all cows consumed their silage ration of $4 \mathrm{~kg}$ of $\mathrm{DM} / \mathrm{d}$.

The milk yield, fat, protein, and lactose contents as well as the $P$-values from the $F$-tests of the fixed effects in the model for these parameters are presented in Table 3. The daily milk yield and lactose content de- 
Table 3. Least squares means (LSM) \pm SE and $F$-tests of fixed effects included in the model for daily milk yield, fat, protein and lactose percentage, and SCC in milk before and during DO in 56 dairy cows ${ }^{1}$

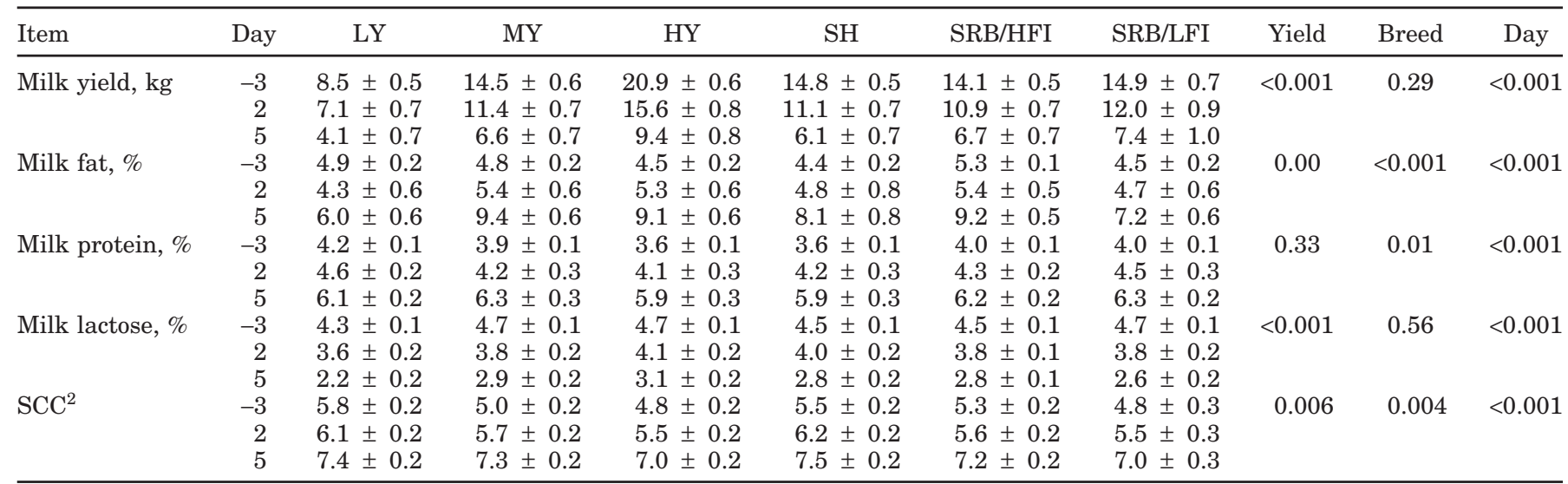

${ }^{1}$ Fixed effects are Yield (LY: 5.0 to $11.4 \mathrm{~kg}$ of milk/d; MY: 11.5 to $17.7 \mathrm{~kg}$ of milk/d; and HY: 17.8 to $29.5 \mathrm{~kg}$ of milk/d), Breed [Swedish Red and White (SRB) and Swedish Holstein (SH)], and sample day (Day). HFI = high milk fat percentage; LFI = low milk fat percentage.

${ }^{2}$ Log-transformed values.

creased, whereas the milk fat and protein content increased during DO in all 3 groups. The rise in milk fat percentage at d 5 was higher $(P=0.001)$ in the MY and HY groups than in the LY group. The overall fat content was higher $(P<0.001)$ in SRB/HFI cows than in SRB/LFI and $\mathrm{SH}$ cows during DO. Overall, there was an effect of yield on milk lactose, and the LY group had the lowest values.

\section{Plasma Cortisol, NEFA, Glucose, Insulin, $B H B A$, and Urea}

The plasma concentrations of cortisol, NEFA, glucose, insulin, BHBA, and urea are presented in Figures 1,2 , and 3 , and the $P$-values from the $F$-tests of the fixed effects in the model for these components are presented in Table 4. Plasma cortisol increased on d 3 during DO, compared with before DO, within each yield group but the increase was not significant in the LY group. After the DO period, the concentrations returned to the same levels as before DO, except in HY at d 8. Overall, the LY group had lower $(P<0.001)$ plasma cortisol levels than the other groups. Multiparous cows $(10.79 \pm 0.69 \mathrm{mmol} / \mathrm{L})$ tended $(P=0.05)$ to have higher concentrations compared with primiparous cows $(9.12 \pm 0.52 \mathrm{mmol} / \mathrm{L})$.

Milk yield had a significant effect on plasma NEFA, with higher levels in the HY group than in the LY group $(P=0.02)$. Plasma NEFA increased markedly during DO in all yield groups, peaked at d 3, and decreased thereafter, reaching pre-DO values on $\mathrm{d} 12$. The peak was most pronounced in the HY group.

There were no yield effects on plasma insulin and glucose concentrations. The numerically lowest within-group insulin level was found on $\mathrm{d} 3$ in all yield groups, but the insulin level was significantly lower than prior to DO only in the HY group (Figure 2). The CI-15 group tended to have higher insulin levels in plasma before DO than did the CI-12 group (1.12 \pm $0.10 \mathrm{ng} / \mathrm{mL}$ and $0.93 \pm 0.06 \mathrm{ng} / \mathrm{mL}$, respectively; $P<$ 0.001 ), whereas the plasma glucose concentration was significantly higher in the CI-15 group $(3.64 \pm 0.06$ $\mathrm{mmol} / \mathrm{L})$ compared with the CI-12 group $(3.39 \pm 0.03$ $\mathrm{mmol} / \mathrm{L}$ ). The primiparous cows had lower mean values compared with the multiparous cows $(3.42 \pm 0.04$ $\mathrm{mmol} / \mathrm{L}$ and $3.62 \pm 0.05 \mathrm{mmol} / \mathrm{L}$, respectively).

A decrease in plasma urea was observed from $d 3$ during DO and throughout the study in all yield groups. Plasma urea was affected by parity, with lower values in primiparous cows $(3.89 \pm 0.11 \mathrm{mmol} / \mathrm{L})$ than in multiparous cows $(4.31 \pm 0.15 \mathrm{mmol} / \mathrm{L})$. The plasma concentration of BHBA decreased somewhat during the DO period in all groups and remained lower than before DO during the study. Overall, the LY group $(0.41 \pm 0.02 \mathrm{mmol} / \mathrm{L})$ had lower $(P<0.001)$ plasma BHBA than did the MY $(0.50 \pm 0.02 \mathrm{mmol} / \mathrm{L})$ and HY $(0.53 \pm 0.02 \mathrm{mmol} / \mathrm{L})$ groups. Primiparous cows $(0.43$ $\pm 0.01 \mathrm{mmol} / \mathrm{L}$ ) had lower mean plasma BHBA levels than multiparous cows $(0.53 \pm 0.02 \mathrm{mmol} / \mathrm{L})$. Breed affected the BHBA concentration, with a higher overall concentration in SRB cows $(0.51 \pm 0.01 \mathrm{mmol} / \mathrm{L})$ than in $\mathrm{SH}$ cows $(0.46 \pm 0.02 \mathrm{mmol} / \mathrm{L})$.

\section{Disease Incidence}

From DO to 2 mo after calving, $11 \%$ of the cows suffered from clinical mastitis and $27 \%$ suffered from some other clinical disease (mainly puerperal paresis). 

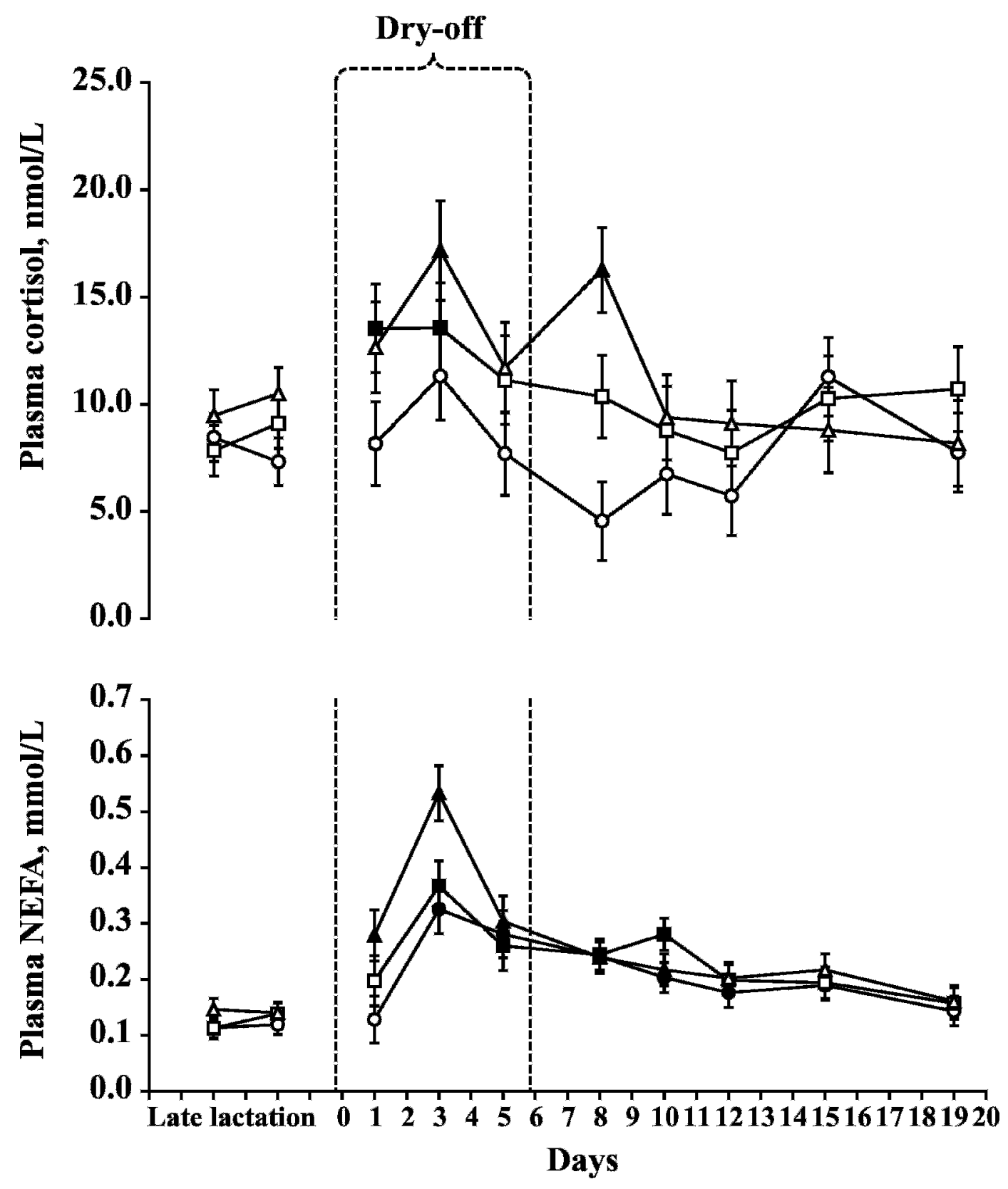

Figure 1. Least squares means \pm SEM plasma concentrations of NEFA and cortisol around dry-off (DO). The symbols represent dairy cows from 3 different DO yield groups: low (LY; $\bigcirc, 5.0$ to $11.4 \mathrm{~kg}$ of milk/d), medium (MY; $\square, 11.5$ to $17.7 \mathrm{~kg}$ of milk/d), and high (HY; $\triangle$, 17.8 to $29.5 \mathrm{~kg}$ of milk/d). Values that differ $(P<0.05)$ from the control value before DO (mean from 2 samples) within treatment are indicated with filled symbols.

The disease incidence did not differ among the LY, MY, and HY groups, between breeds, or by CI.

\section{Milk SCC and Bacteriology}

Milk SCC prior to and during DO is presented in Table 3. The log SCC increased significantly $(P<0.001)$ at the 2 milkings during $\mathrm{DO}$, compared with prior to
DO, in all groups. The LY cows had higher SCC overall compared with the MY and the HY cows $(P=0.05$ and $P<0.001$, respectively). The SRB/HFI and SRB/LFI cows had significantly lower log SCC prior to DO compared with the SH cows $(P<0.04$ and $P<0.004$, respectively). The log SCC decreased again in the 4 weekly samples postparturition in all groups, and the same differences were again found between the breed groups 

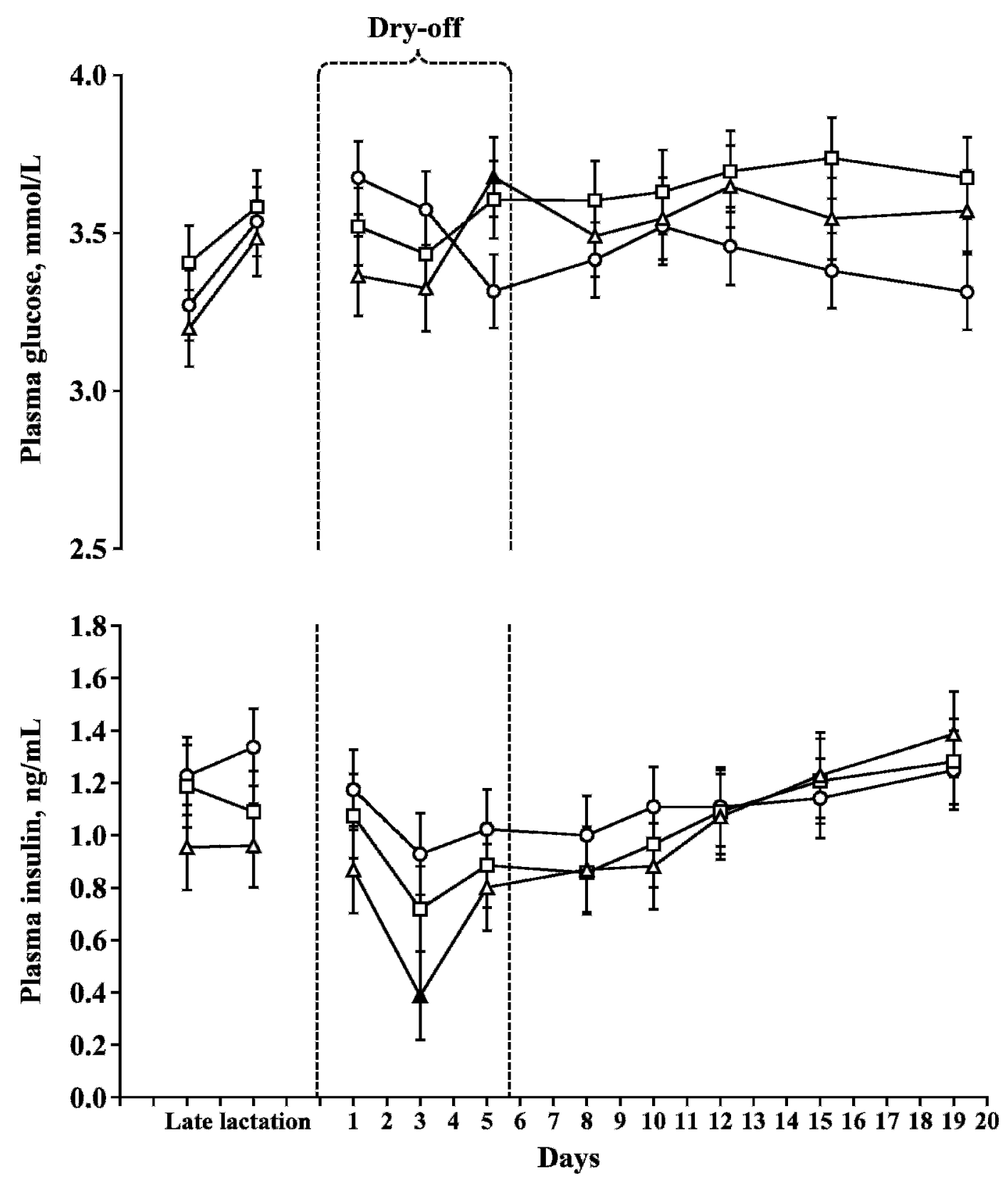

Figure 2. Least squares means \pm SEM plasma concentrations of glucose and insulin around dry-off (DO). The symbols represent dairy cows from 3 different DO yield groups: low (LY; $\bigcirc, 5.0$ to $11.4 \mathrm{~kg}$ of milk/d), medium (MY; $\square, 11.5$ to $17.7 \mathrm{~kg}$ of milk/d), and high (HY; $\triangle$, 17.8 to $29.5 \mathrm{~kg}$ of milk/d). Values that differ $(P<0.05)$ from the control value before DO (mean from 2 samples) within treatment are indicated with filled symbols.

as prior to DO. The overall $\log \mathrm{SCC} / \mathrm{mL}$ for the 4 -wk period postparturition were $2.50 \pm 0.05,2.35 \pm 0.07$, and $2.68 \pm 0.06$ for SRB/HFI, SRB/LFI, and SH, respectively. There were no differences in log SCC among the yield groups postparturition.

Overall, the proportions of cows with IMI at PD4, DO, PP1, and PP4 were $26.8,42.8,39.3$, and $23.2 \%$, respectively. The proportion of cows with IMI was sig- nificantly lower in LY than in MY $(P=0.039)$ and HY $(P=0.013)$ at PP1. The proportions of udder quarters with IMI (all udder pathogens) are presented in Table 5. The proportions with IMI (all udder pathogens) at PD4, DO, PP1, and PP4 were 13.4, 17.8, 18.3, and $8.0 \%$, respectively, with lower $(P<0.05)$ numbers in LY than in MY and HY at PD4 and PP1. At all time points, minor pathogens were more common than ma- 

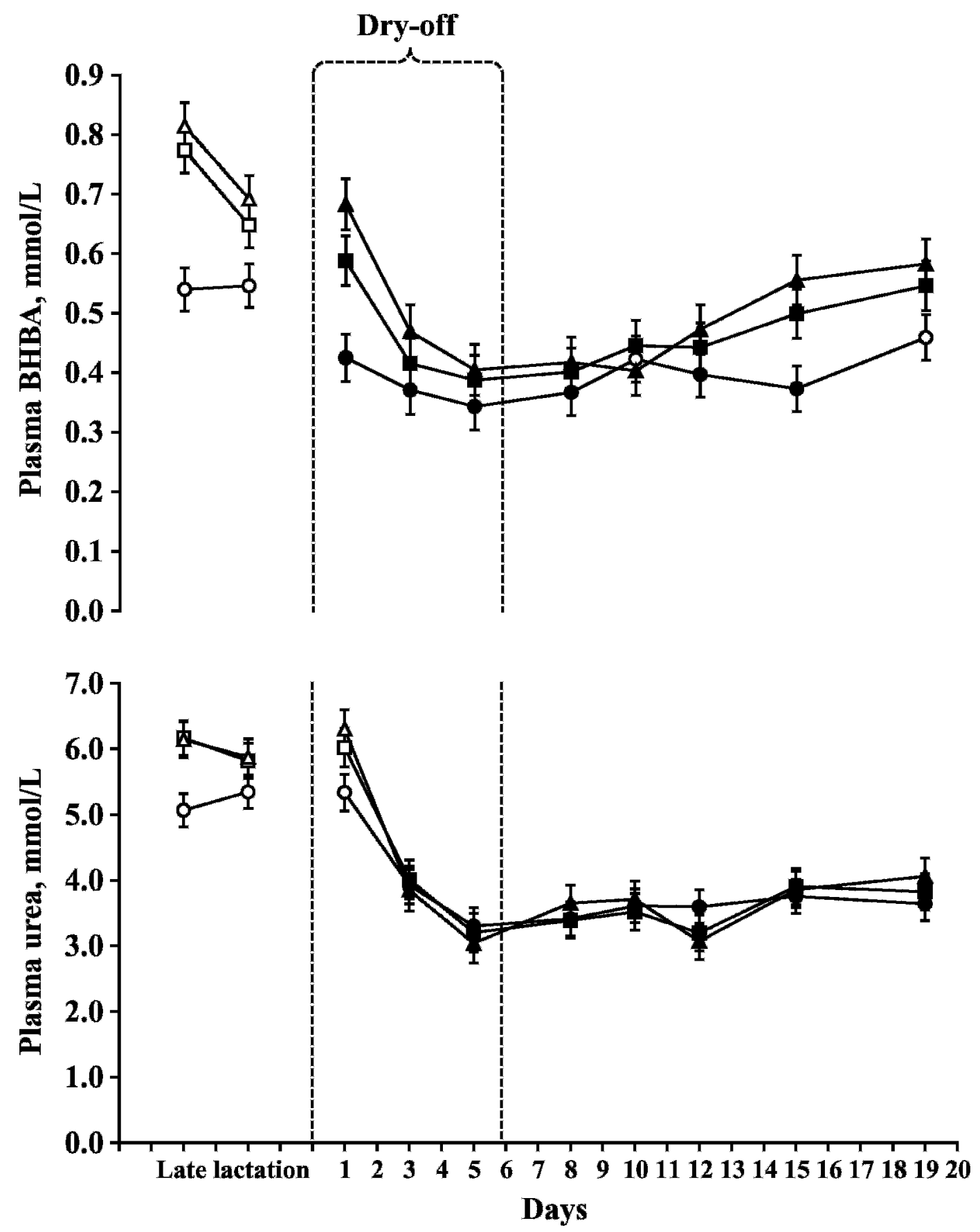

Figure 3. Least squares means \pm SEM plasma concentrations of BHBA and urea around DO. The symbols represent dairy cows from 3 different DO yield groups: low (LY; $\bigcirc, 5.0$ to $11.4 \mathrm{~kg}$ of milk/d), medium (MY; $\square, 11.5$ to $17.7 \mathrm{~kg}$ of milk/d), and high (HY; $\triangle, 17.8$ to 29.5 $\mathrm{kg}$ of milk/d). Values that differ $(P<0.05)$ from the control value before DO (mean from 2 samples) within treatment are indicated with filled symbols.

jor pathogens. When studying only major pathogens, significantly fewer IMI were found at PP1 in LY compared with MY $(P=0.016)$ and HY $(P=0.040)$. Overall, CNS (61/131 diagnoses) was the most common bacteriological finding, followed by $C$. bovis (33/131). The fol- lowing major pathogens were found: Streptococcus $u b$ eris (11/131), Streptococcus dysgalactiae (7/131), Enterococcus spp. (6/131), Escherichia coli (6/131), Staphylococcus aureus (4/131), Arcanobacterium pyogenes (2/131), and Streptococcus spp. (1/131). 
Table 4. $P$-values from the $F$-tests of fixed effects included in the model for plasma concentrations of cortisol, NEFA, insulin, glucose, BHBA, and urea ${ }^{1}$

\begin{tabular}{lcllcccc}
\hline Item & Yield & Breed & CI & Par & Day & Yield $\times$ Day & CI $\times$ Day \\
\hline Cortisol & $<0.001$ & 0.46 & 0.38 & 0.05 & $<0.001$ & 0.24 & 0.69 \\
NEFA & 0.02 & 0.96 & 0.38 & 0.67 & $<0.001$ & 0.22 & 0.76 \\
Glucose & 0.11 & 0.57 & 0.001 & 0.006 & 0.32 & 0.46 & 0.48 \\
Insulin & 0.25 & 0.15 & 0.06 & 0.98 & $<0.001$ & 0.67 & 0.05 \\
BHBA & $<0.001$ & 0.047 & 0.79 & $<0.001$ & $<0.001$ & 0.11 & 0.61 \\
Urea & 0.21 & 0.35 & 0.88 & 0.006 & $<0.001$ & 0.11 & 0.25 \\
\hline
\end{tabular}

${ }^{1}$ Fixed effects are Yield (LY: 5.0 to $11.4 \mathrm{~kg}$ of milk/d; MY: 11.5 to $17.7 \mathrm{~kg}$ of milk/d; and HY: 17.8 to 29.5 $\mathrm{kg}$ of milk/d), Breed [Swedish Red and White (SRB) and Swedish Holstein (SH)], calving interval (CI: 12 mo and 15 mo), parity (Par), sample day (Day), and the interaction between Yield $\times$ Day, and CI $\times$ Day.

\section{Milk Leakage, Teat-End Condition, and Teat-End Closure}

Milk leaking from the teats between or just before milking was observed on 1 to 3 occasions in each of 5 cows (0 LY, $3 \mathrm{MY}$, and $2 \mathrm{HY}$ cows) during DO. Among the 37 cows examined for teat-end condition and closure, 16, 13, and 8 cows belonged to the LY, MY, and HY groups, respectively. Rough callosity (scores $2 \mathrm{~A}$ to C) was found in $6(4 \%)$ teats of $3(8 \%)$ cows (1 cow in each yield group), whereas varying degrees (scores $1 \mathrm{~A}$ to D) of smooth callosity were found in $63(42 \%)$ teats in $25(67 \%)$ cows. The results did not indicate any difference between production groups. The proportions of open teats during the wk after DO are presented in Figure 4. The proportions of cows scored open on at least 1 occasion were 38,46, and 63\% in the LY, MY, and HY groups, respectively. The corresponding proportions of open udder quarters were 11,17 , and $25 \%$. The proportion of open udder quarters was lower $(P=$ 0.047) in LY than in HY, but no other significant differences were found. When conducting each weekly observation (wk 1 to 5 ), differences were found at wk 2 and 3 after DO. At wk 2 , fewer cows $(P=0.046)$ and udder quarters $(P=0.002)$ were open in LY cows than in HY cows, whereas fewer cows $(P=0.036)$ and udder quarters $(P=0.014)$ were found open in LY than in MY at wk 3. The proportion of cows or quarters with IMI at PP1 did not differ between cows or quarters

Table 5. Number (\%) of quarters with IMI (all udder pathogens) 4 wk before dry-off (DO) (PD4), during DO, and 1 or 4 wk postparturition (PP1 and PP4) in cows with low (LY; $\mathrm{n}=19$ cows), medium (MY; $\mathrm{n}=19$ cows), or high (HY; $\mathrm{n}=18$ cows) daily milk yield just before DO

\begin{tabular}{lcccc}
\hline Time & $\begin{array}{c}\mathrm{LY}^{1} \\
(\mathrm{n}=76)\end{array}$ & $\begin{array}{c}\mathrm{MY}^{1} \\
\mathrm{n}=76)\end{array}$ & $\begin{array}{c}\mathrm{HY}^{1} \\
(\mathrm{n}=72)\end{array}$ & $\begin{array}{c}\text { Total } \\
(\mathrm{n}=224)\end{array}$ \\
\hline PD4 & $4^{\mathrm{a}}(5.3)$ & $11^{\mathrm{b}}(14.5)$ & $15^{\mathrm{b}}(20.8)$ & $30(13.4)$ \\
DO & $12^{\mathrm{a}}(15.8)$ & $16^{\mathrm{a}}(21.0)$ & $12^{\mathrm{a}}(16.7)$ & $40(17.8)$ \\
PP1 & $3^{\mathrm{a}}(3.9)$ & $19^{\mathrm{b}}(25.0)$ & $19^{\mathrm{b}}(26.4)$ & $41(18.3)$ \\
PP4 & $4^{\mathrm{a}}(5.3)$ & $8^{\mathrm{a}}(10.5)$ & $6^{\mathrm{a}}(8.3)$ & $18(8.0)$ \\
\hline
\end{tabular}

${ }^{\mathrm{a}, \mathrm{b}}$ Values with different letters within a row $\operatorname{differ}(P<0.05)$. that were scored as closed on all occasions and cows that were scored as open.

\section{DISCUSSION}

The design of the present study enabled us to investigate how the level of milk production prior to DO affected the cow during and after DO. The NEFA concentration in plasma peaked on the third day of the DO period, indicating a nadir in energy balance. The maximum NEFA concentration was related to milk production prior to dry-off. A rise in NEFA during DO has been shown previously, and was suggested primarily to reflect negative energy balance (Odensten et al., 2005a). The energy intake during DO in the present study did not differ between cows with varying yields, but milk yield at the milkings during DO was related to milk yield prior to DO. Thus, the energy balance during DO was presumably negatively related to milk production prior to DO. The insulin level in plasma dropped during the DO period and reached the nadir

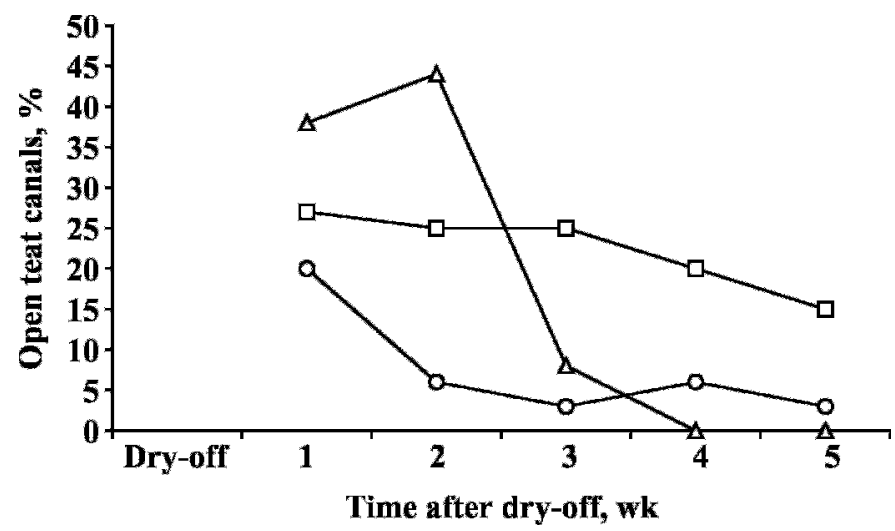

Figure 4. Proportions of quarters with open teats at wk 1 to 5 after dry-off (DO). The symbols represent dairy cows from 3 different yield groups: low (LY; $\bigcirc, 5.0$ to $11.4 \mathrm{~kg}$ of milk/d), medium (MY; $\square$, 11.5 to $17.7 \mathrm{~kg}$ of milk/d), and high (HY; $\triangle, 17.8$ to $29.5 \mathrm{~kg}$ of milk/ d). Overall, the proportion of open udder quarters was lower $(P=$ 0.047) in LY than in HY. 
at the third day of DO. The drop was significant only among HY cows. This strengthens the indication that HY cows were in a lower energy balance than the other cows during the first days of the DO period. The plasma glucose level was significantly elevated at d 5 of DO. The increase might partly be an effect of the reduced drainage of glucose by the mammary gland. The low insulin level probably aided the increase in glucose. We have previously observed that plasma glucose was elevated during DO in cows receiving silage during DO (Odensten et al., 2005). These results show that the cows adapted to the physiological changes induced by the DO procedure.

In the present study, only MY and HY cows had elevated plasma cortisol concentrations during DO. We previously observed that cows fed only straw during DO had higher cortisol levels in blood than cows fed straw plus $4 \mathrm{~kg}$ of DM/d as silage, which may have been due to a more pronounced negative energy balance in the group fed straw only (Odensten et al., 2007). However, in early-lactation cows the degree of negative energy balance is not related to the plasma level of cortisol (Beerda et al., 2004). It is possible that the elevated cortisol levels in the present study were related to a higher intramammary pressure in cows with a higher milk production at DO. In HY cows, the cortisol level was elevated also at $2 \mathrm{~d}$ after the end of the DO period. At this time, the differences in energy balance should have been negligible, but the intramammary pressure may still have been significant. However, a relationship between cortisol and energy balance cannot be ruled out because the HY cows were assumed to be in a lower energy balance during the DO period.

In agreement with a previous study (Odensten et al., 2005a), lactose secretion decreased markedly in milk during DO, whereas the drop in secretion of milk protein and fat was less prominent. The drop in lactose concentration has been shown to occur concomitantly with an increased concentration of Na in milk (Stelwagen et al., 1994). Most probably, the Na concentration in milk increased during DO in the present study, and this might have contributed to the reduced milk secretion (Allen, 1990). The cessation of milking, causing increased intramammary pressure, may have reduced the activity of key mammary enzymes and thus reduced the metabolic capacity and production of milk lactose (Farr et al., 2000). An increased permeability of tight junctions of the mammary epithelium, causing paracellular leakage of lactose to blood plasma, may have contributed to the decreased lactose concentration in milk (Stelwagen et al., 1994). Reduction of feed also influences lactose secretion, and complete feed withdrawal results in a pronounced drop in lactose secretion in ruminants (Chaiyabutr et al., 1980; Agenäs et al., 2003). On the other hand, a $50 \%$ restriction of feed intake in late lactation induced a nonsignificant reduction in lactose secretion (Lacy-Hulbert et al., 1999). In the present study, the feed restriction imposed by the DO procedure was considered to be modest because the cows were fed $4 \mathrm{~kg}$ of DM as silage as well as straw ad libitum. It is therefore reasonable to assume that the effects of feed restriction on lactose output were limited. Thus, the observed reduction in lactose output was probably caused mainly by increased intramammary pressure because of prolonged milking intervals. However, other explanations are also possible.

The BHBA concentration was generally higher in HY and MY cows than in LY cows but dropped in all cows during DO, in agreement with Odensten et al. (2005a). It is probable that the drop mainly reflected a reduction in rumen absorption and epithelial oxidation of butyrate, and not the rate of liver ketogenesis (Aiello et al., 1984). The plasma urea concentration decreased during DO in all cows. We previously showed that rumen ammonia dropped markedly, concomitant with a drop in plasma urea, during DO (Odensten et al., 2005a). It is reasonable to assume that the reduction in plasma urea concentration reflects a decreased $\mathrm{N}$ intake.

In spite of a generally slightly higher milk production in the $\mathrm{SH}$ breed, there were no breed differences in milk yield at DO in our study. It is probable that the number of animals was too small to detect differences between breeds. Moreover, no interactions between breed and days relative to DO were found in any of the measured milk and plasma parameters, suggesting that the breeds responded equally to the DO procedure. As expected, SRB cows had a higher fat content in milk than did SH cows (Swedish Dairy Association, 2005). They also tended to have higher plasma concentrations of BHBA than did SH cows. A relation between milk fat and ketone bodies has been reported previously (Miettinen and Sätelä, 1993). Ketosis is also more common in SRB cows than in SH cows (Emanuelson et al., 1993).

There was no effect of calving interval on milk yield or composition. Plasma glucose was significantly higher and insulin tended to be higher in CI-15 cows than in CI-12 cows. This probably reflects a more positive energy balance among the CI-15 cows than the CI-12 cows. The CI-15 cows also had higher BCS at DO. In line with Österman et al. (2005), the cows in the CI-15 group in the present study did not have higher SCC prior to DO compared with the CI-12 cows.

In agreement with previous studies (Emanuelson et al., 1988; Odensten et al., 2007), the SCC, at both 
the cow and quarter levels, was significantly elevated during DO as compared with late lactation. This was especially true in low-yielding cows. In cows with good udder health, the elevated SCC at DO is mainly due to a concentration effect as the milk production decreases and to cell migration during involution of the mammary gland. However, there is also an increased risk of IMI during DO that gives rise to an increase in SCC. In line with other studies (Dingwell et al., 2004; Rajala-Schultz et al., 2005), IMI was less common immediately following calving in cows producing a lower milk yield at DO. This may have been due to the less common finding of open teat canals after DO in this group compared with the higher yielding groups. In the present study, which included a relatively small number of animals and quarters, we did not find a significant relationship between teat canal closure and IMI at calving. However, such an association was reported by Dingwell et al. (2004) using a much larger population. In another study, cows with milk leakage after DO as a result of incomplete teat canal closure were 4-fold more likely to develop clinical mastitis (Schukken et al., 1993). Teat-end condition has also been associated with IMI (Neijenhuis et al., 2001), but in the present study, teat condition did not differ between yield groups after DO. In the present study, the yield before DO did not significantly influence the SCC during the first 4 wk after parturition or the presence of IMI 4 wk after parturition, indicating a limited long-term influence on udder health. An effect of breed (lower SCC in SRB than in SH) was obvious before and during DO, as well as after parturition. This is consistent with a lower incidence of subclinical mastitis in SRB cows than in SH cows (Emanuelson et al., 1993; Swedish Dairy Association, 2005).

\section{CONCLUSIONS}

In the present study, all cows were fed $4 \mathrm{~kg}$ of DM/ $\mathrm{d}$ as silage and straw ad libitum during the DO period of $5 \mathrm{~d}$. Higher milk yield ( $>18 \mathrm{~kg} / \mathrm{d}$ ) prior to DO gave rise to a more pronounced metabolic response during the 5-d DO period and a higher risk of contracting IMI during DO and at calving, but had no long-term effects on udder health. Neither CI nor breed had a marked influence on the results.

\section{ACKNOWLEDGMENTS}

Financial support from the Swedish Farmer's Foundation for Agricultural Research (No. 0230021), and the Animal Welfare for Quality in Food Production project at the Swedish University of Agricultural Sciences, are gratefully acknowledged. The authors thank
Gudrun Franzén and Lena Hagenvall for technical assistance in the barn.

\section{REFERENCES}

Agenäs, S., K. Dahlborn, and K. Holtenius. 2003. Changes in metabolism and milk production during and after feed deprivation in primiparous cows selected for different milk fat content. Livest. Prod. Sci. 83:153-164.

Aiello, R. J., T. M. Kenna, and J. H. Herbein. 1984. Hepatic gluconeogenic and ketonic intrerrelationhips in the lactating cow. J. Dairy Sci. 67:1707-1715.

Allen, J. C. 1990. Milk synthesis and secretion rates in cows with milk composition changed by oxytocin. J. Dairy Sci. 73:975-984.

Arbel, R., Y. Bigun, E. Ezra, H. Sturman, and D. Hojman. 2001. The effect of extended calving intervals in high-yielding lactating cows on milk production and profitability. J. Dairy Sci. 84:600-608.

Beerda, B., J. E. Kornalijnslijper, J. T. N. van der Werf, E. N. Noordhuizen-Stassen, and H. Hopster. 2004. Effects of milk production capacity and metabolic status on HPA function in early postpartum dairy cows. J. Dairy Sci. 87:2094-2102.

Brand, A., and M. Warner. 1997. Monitoring reproductive performance. Page 289 in Herd Health and Production Management in Dairy Practice. A. Brand, J. Noordhuizen, and Y. Schukken, ed. Wageningen Pers, Wageningen, the Netherlands.

Chaiyabutr, N., A. Faulkner, and M. Peaker. 1980. The utilization of glucose for the synthesis of milk components in the fed and starved lactating goat in vivo. Biochem. J. 186:301-308.

Dingwell, R. T., K. E. Leslie, Y. H. Schukken, J. M. Sargeant, L. L. Timms, T. F. Duffield, G. P. Keefe, D. F. Kelton, K. D. Lissemore, and J. Conklin. 2004. Association of cow and quarter-level factors at drying-off with new intramammary infections during the dry period. Prev. Vet. Med. 63:75-89.

Emanuelson, U., T. Olsson, T. Mattila, G. Astrom, and O. Holmberg. 1988. Effects of parity and stage of lactation on adenosine triphosphate, somatic cell count and antitrypsin content in cows' milk. J. Dairy Res. 55:49-55.

Emanuelson, U., P. A. Oltenacu, and Y. Grohn. 1993. Nonlinear mixed-model analyses of 5 production disorders of dairy cattle. J. Dairy Sci. 76:2765-2772.

Farr, V. C., C. G. Prosser, and S. R. Davis. 2000. Effects of mammary engorgement and feed withdrawal on microvascular function in lactating goat mammary glands. Am. J. Physiol. Heart Circ. Physiol. 279:813-818.

Goering, H. K., and P. J. Van Soest. 1970. Forage Fiber Analyses (Apparatus, Reagents, Procedures, and Some Applications). Agric. Handbook No. 379. ARS-USDA, Washington, DC.

Janson, L. 1993. Vad händer vid urval för låg respektive hög mjölkfetthalt? Page N22 in SLU info rapporter. Allmänt 181. Swedish Univ. of Agric. Sci., Uppsala, Sweden. (in Swedish)

Lacy-Hulbert, S. J., M. W. Woolford, G. D. Nicholas, C. G. Prosser, and K. Stelwagen. 1999. Effect of milking frequency and pasture intake on milk yield and composition of late lactation cows. J. Dairy Sci. 82:1232-1239.

Lindgren, E. 1979. Vallfodrets näringsvärde bestämt in vitro och med olika laboratoriemetoder. Rapport 45. Department of Animal Nutrition and Management, Swedish Univ. of Agric. Sci., Uppsala, Sweden. (in Swedish with English summary)

McFadden, T. B., M. R. Callagan, and S. R. Davis. 1995. Regulation of lactose production by ovine mammary acini in culture. Proc. New Zeal. Soc. Anim. Prod. 55:17-20.

Miettinen, P. V., and J. J. Sätelä. 1993. Relationships between subclinical ketosis, milk production and fertility in Finnish dairy cattle. Prev. Vet. Med. 17:1-8.

Neijenhuis, F., H. W. Barkema, H. Hogeveen, and J. P. Noordhuizen. 2000. Classification and longitudinal examination of callused teat ends in dairy cows. J. Dairy Sci. 83:2795-2804.

Neijenhuis, F., H. W. Barkema, H. Hogeveen, and J. P. Noordhuizen. 2001. Relationship between teat-end callosity and occurrence of clinical mastitis. J. Dairy Sci. 84:2664-2672. 
Odensten, M. O., Y. Chilliard, and K. Holtenius. 2005. Effects of two different feeding strategies during dry-off on metabolism in high-yielding dairy cows. J. Dairy Sci. 88:2072-2082.

Odensten, M. O., K. Persson Waller, and K. Holtenius. 2007. Effects of two different feeding strategies during dry-off on certain health aspects of high-yielding dairy cows. J. Dairy Sci. 90:898-907.

Österman, S., and J. Bertilsson. 2003. Extended calving intevals in combination with milking two or three times per day: Effects on milk production and milk composition. Livest. Prod. Sci. 82:139-149.

Österman, S., K. Östensson, K. Svennersten-Sjaunja, and J. Bertilsson. 2005. How does extended lactation in combination with different milking frequencies affect somatic cell count in dairy cows. Livest. Prod. Sci. 96:225-232.

Rajala-Schultz, P. J., J. S. Hogan, and K. L. Smith. 2005. Association between milk yield at dry-off and probability of intramammary infections at calving. J. Dairy Sci. 88:577-579.

Ratnayake, D. R. T. G., B. Berglund, J. Bertilsson, M. Forsberg, and H. Gustafsson. 1998. Fertility in dairy cows managed for calving intervals of 12,15 or 18 months. Acta Vet. Scand. 39:215-228.

Rehn, H., N. Berglund, U. Emanuelson, G. Tengroth, and J. Philipsson. 2000. Milk production in Swedish dairy cows for calving intervals of 12 and 15 months. Acta Agric. Scand. 50:263-271.
SAS Institute. 2001. SAS/Stat Software. Proprietary Software Release 8.2 (TS2M0). SAS Inst., Inc., Cary, NC.

Schukken, Y. H., J. Vanvliet, D. Vandegeer, and F. J. Grommers. 1993. A randomized blind trial in dry cow antibiotic infusion in a low somatic cell herd. J. Dairy Sci. 76:2925-2930.

Shennan, D. B., and M. Peaker. 2000. Transport of milk constituents by the mammary gland. Physiol. Rev. 80:925-951.

Skidmore, A., K. Peeters, C. Sniffen, and A. Brand. 1997. Monitoring dry period management. Page 173 in Herd Health and Production Management in Dairy Practice. A. Brand, J. Noordhuizen and Y. Schukken, ed. Wageningen Pers, Wageningen, the Netherlands.

Spörndly, R. 2003. Fodertabell för idisslare. Rapport 257. Dept. of Anim. Nutr. and Management, Swedish Univ. of Agri. Sci., Uppsala, Sweden. (in Swedish)

Stefano, B., M. Colitti, G. Gabai, C. H. Knight, and C. J. Wilde. 2002. Mammary apoptosis and lactation persistency in dairy animals. J. Dairy Res. 69:37-52.

Stelwagen, K., S. R. Davis, V. C. Farr, C. G. Prosser, and R. A. Sherlock. 1994. Mammary epithelial cell tight junction integrity and mammary blood flow during an extended milking interval in goats. J. Dairy Sci. 77:426-432.

Strandberg, E., and P. A. Oltenacu. 1989. Economic consequences of different calving intervals. Acta Agric. Scand. 39:407-420.

Swedish Dairy Association. 2005. Cattle Statistics 2005. Swedish Dairy Association, Hållsta, Eskilstuna, Sweden. 